Original research article

\title{
The influence of lifestyle on the quality of life and body composition of women at productive age
}

\author{
Simona Šimková ${ }^{1 *}$ (iD), Pavel Kohout ${ }^{1,2,3}$ iD \\ ${ }^{1}$ University of South Bohemia in České Budějovice, Faculty of Health and Social Sciences, Institute of Laboratory Diagnostics and Public Health, \\ České Budějovice, Czech Republic \\ ${ }^{2}$ Thomayer University Hospital, Prague, Czech Republic \\ ${ }^{3}$ Charles University, Third Faculty of Medicine, Department of Internal Medicine, Prague, Czech Republic
}

\begin{abstract}
Overweight and obesity fall into the category of diseases of civilization. Being overweight causes other diseases. Excessive weight is often the cause of poor quality of life.

Goal: This paper aims to evaluate the relationship between selected health and social aspects and proper nutrition, discover how lifestyle affects BMI, and body composition, especially fatty tissue, identify the relationship between BMI and the quality of life, compare the quality of life of respondents to population norms, and find out whether there are differences between indicators depending on BMI. Methods: We used BMI to evaluate obesity. We mapped the relationship between body weight, body composition, lifestyle, and quality of life. We obtained data using questionnaires. The first questionnaire focused on the respondents' lifestyles. The WHOQOL-BREF standardized questionnaire was used second. Furthermore, the respondents underwent a body composition analysis using bioimpedance with the InBody 270 device. The research group included 81 women aged 18-41. The sample group was divided into two groups according to BMI values.

Results: The average BMI value in the groups of women divided according to BMI was $20.9 \mathrm{~kg} / \mathrm{m}^{2}\left(16.7-24.3 \mathrm{~kg} / \mathrm{m}^{2}\right)$, the proportion of body fat averaged $24.8 \%(13.4-37.3 \%)$, or $30.8 \mathrm{~kg} / \mathrm{m}^{2}\left(25.4-44.8 \mathrm{~kg} / \mathrm{m}^{2}\right)$, body fat content averaged $38.9 \%(29.5-51.9 \%)$. In terms of lifestyle, differences arose in the frequency of food consumption and physical activities. When comparing the quality of life with population norms, there were differences in all evaluated domains.
\end{abstract}

Keywords: BMI; Body composition; Lifestyle; Quality of life; WHOQOL-BREF

\section{Introduction}

Overweight and obesity are a global problem, and the incidence of these diseases is constantly increasing (Pan et al., 2011). According to the World Health Organization (WHO, 2021a), overweight is defined as a BMI higher than $25 \mathrm{~kg} / \mathrm{m}^{2}$, and obesity as a BMI over $30 \mathrm{~kg} / \mathrm{m}^{2}$.

BMI (Body Mass Index) or Quetelet's body mass index is the relationship between body weight and body height.

$$
\mathrm{BMI}=\frac{\text { body weight }(\mathrm{kg})}{\text { height }^{2}(\mathrm{~m})}
$$

The prevalence of overweight and obesity can be looked upon as a global pandemic. Each year, over 4 million people die worldwide due to being overweight (WHO, 2021b). The WHO (2021b) states that 1.9 billion people were overweight, and 650 million people were obese in 2016, corresponding to $39 \%$ of overweight adults, and $13 \%$ of the obese.
Both diseases are defined as an increase in fatty tissue in the body. Donini et al. (2013) state that body composition measurement is not a standard diagnostic method. We commonly use body mass index (BMI) calculation. BMI is a helpful tool for epidemiological studies, but it can be limited to individuals. The physiological value of BMI ranges from 18.5 to $25 \mathrm{~kg} / \mathrm{m}^{2}$. Values below $18.5 \mathrm{~kg} / \mathrm{m}^{2}$ indicate underweight, or undernourishment, values above $25 \mathrm{~kg} / \mathrm{m}^{2}$ indicate overweight, and values above $30 \mathrm{~kg} / \mathrm{m}^{2}$ indicate obesity.

Examination using DEXA (dual-energy X-ray absorptiometry) is used for the analysis of bone, muscle, and fat mass in the body. Bioimpedance measurements can be used for measuring water content, muscle, and fatty tissue if DEXA is not available. Zhou et al. (2019) point to the diversity of data obtained using DEXA and bioimpedance. Therefore, it is always ideal to perform measurements with one method.

The quality of life results from many factors (social, health, economic) and environmental influences. It is caused by their mutual interaction. It also includes a subjective perception of life (Dvořáčková, 2012). Furthermore, it is based on the fact

\footnotetext{
* Corresponding author: Simona Šimková, University of South Bohemia in České Budějovice, Faculty of Health and Social Sciences, Institute of Laboratory Diagnostics and Public Health, J. Boreckého 1167/27, 37011 České Budějovice, Czech Republic, e-mail: simkovas@zsf.jcu.cz; http://doi.org/10.32725/kont.2022.005

Submitted: 2021-09-24 • Accepted: 2022-02-07 • Prepublished online: 2022-02-16

KONTAKT 24/1: 85-91 • EISSN 1804-7122 • ISSN 1212-4117

(c) 2022 The Authors. Published by University of South Bohemia in České Budějovice, Faculty of Health and Social Sciences.

This is an open access article under the CC BY-NC-ND license.
} 
that although a disease may worsen the quality of life, the person may perceive themselves differently from the environment.

Over the years, several tools have been developed to enable objective evaluation. The tools created for quality of life assessment include WHOQOL-100, which consists of 100 questions. It is sometimes considered too difficult to fill in, so a shorter version of WHOQOL-BREF was created. This questionnaire consists of 26 questions in 4 domains and 2 items that assess the quality of life and health status (Dragomirecká and Bartoňová, 2006). Quality of life is an essential aspect of a happy life. As the quality of life is affected by many factors, we selected some of them. We dealt with the relationship between selected factors, especially lifestyle and anthropometric measurements, and their possible impact on the quality of life.

Lifestyle is closely related to the quality of life. We can influence our health status and thus indirectly our quality of life. These are groups of factors that are closely related and interrelated.

This paper aims to evaluate selected health and social aspects concerning proper nutrition, discover the relationship between body weight (BMI) and lifestyle, quality of life, and body composition, especially the amount of fatty tissue, identify how body weight affects the quality of life of selected women, find out if there are differences between the indicators depending on the BMI, and compare the quality of life of respondents with population norms.

\section{Materials and methods}

\section{Sample group}

The research group consisted of adult women aged 18-41. They voluntarily participated in the research. Respondents with pacemakers and pregnant women were excluded from the study. The total number of respondents was 81 .

The respondents were divided into two groups, namely the low body weight group (BMI $<25 \mathrm{~kg} / \mathrm{m}^{2}$ ) and the high body weight group (BMI $>25 \mathrm{~kg} / \mathrm{m}^{2}$ ). The first group included $49 \mathrm{re-}$ spondents and the second group included 32 respondents. Their permanent residence was in the South Bohemian Region. Low-weight women most often had a secondary school diploma (28 women - 57\%); 35\% (17) had a university degree or higher vocational education; $8 \%$ (4) had a vocational secondary school diploma or primary education.

Women with a high body weight most often had primary or secondary education with an apprenticeship certificate $-40 \%$ (13); 38\% (12) of respondents had secondary school diplomas. The remaining 22\% (7) had a university or higher vocational education. We can see the difference in education. Women with low body weight had particularly secondary education with a secondary school diploma or higher; $40 \%$ of women with high body weight achieved only primary or secondary education without a GCSE.

26 low-weight respondents were students, 21 respondents were employed or in business, and 2 were on parental leave; 14 respondents with a high body weight were students, 16 were employed or in business, one was on parental leave, and one was a housewife.
The average age of low-weight women was 25 years (18 to 39). The average age of high-weight women was 26 years (18 to 41).

28 low-weight women (57\%) were single, 13 lived with a partner, 7 were married, and 1 was divorced; $66 \%$ (21) of highbody weight women were single, 9 were married, one lived with a partner, and one was a widow.

Body composition analysis was performed using an InBody 270 tool, which works on the principle of bioimpedance. An imperceptible weak electric current of various frequencies passes through the body during the measurement. Due to the different water content in the tissues (muscle tissue has a higher amount of water than fat mass and therefore is a better current conductor), the electrical conductivity of individual body segments also differs. The device then uses software to determine the composition of the human body with high accuracy based on measured values and entered variables (height, age, and gender). InBody measurements determine body weight, muscle mass, total body water content, amount and percentage of fat mass, BMI, waist and hip ratio and other calculations.

Quantitative research was carried out using a questionnaire. Standardized and non-standardized tools were used for data collection. The respondents filled in two questionnaires. The first questionnaire of our design focused on lifestyle, and its questions concerned the respondents' eating habits, physical activity, sleep, education, etc. All respondents filled in the standardized questionnaire, WHOQOL-BREF, regarding the quality of life (Dragomirecká and Bartoňová, 2006). The standards listed in WHOQOL-100: Handbook for Users of the Czech Version of the World Health Organization Quality of Life Questionnaires (Dragomirecká and Bartoňová, 2006, p. 42) were used to compare the results of the respondents with the results of the quality of life of the general population.

The completion of both questionnaires and the measurement of individual women's body composition took place within 14 days. Data collection took place from December 2019 to March 2021.

\section{Results}

\section{Selected anthropometric data}

The average weight of female respondents with low body weight was $58.5 \mathrm{~kg}$. The average weight of female respondents with high body weight was $87.7 \mathrm{~kg}$. The average height in both groups was almost the same in both groups: $167 \mathrm{~cm}$ or $169 \mathrm{~cm}$.

The amount of body fat in respondents with high body weight averaged $34.6 \mathrm{~kg}$ ( $\min .19 .8 \mathrm{~kg}$, $\max .64 .9 \mathrm{~kg}$ ). The amount of body fat in respondents with low body weight averaged $14.9 \mathrm{~kg}$ (min. $5.8 \mathrm{~kg}$, max. $25.8 \mathrm{~kg}$ ). We can see that some respondents with low body weight had a higher level of body fat than some respondents with high body weight, i.e., with BMI in the overweight and obesity zone.

All monitored indicators averaged higher in the group of women with higher BMI. However, a significant difference can be observed in visceral fat, where the average level in women with low body weight was $5.8\left(58 \mathrm{~cm}^{2}\right)$. In overweight or obese women, visceral fat level averaged $15.5\left(155 \mathrm{~cm}^{2}\right)$ according to BMI values (Table 1 ). 
Table 1. Average values of the respondents' selected parameters by BMI $(N=81)$

\begin{tabular}{|c|c|c|c|c|c|c|c|c|}
\hline \multirow[t]{2}{*}{ Parameter } & \multicolumn{3}{|c|}{ Low-weight group } & & \multicolumn{4}{|c|}{ High-weight group } \\
\hline & Average & Min. & Max. & Median & Average & Min. & Max. & Median \\
\hline BMI $\left(\mathrm{kg} / \mathrm{m}^{2}\right)$ & 21.0 & 16.7 & 24.3 & 21.15 & 30.6 & 25.4 & 44.8 & 29.9 \\
\hline Body weight & 58.5 & 40.6 & 76.1 & 58.0 & 87.7 & 66.7 & 124.9 & 84.9 \\
\hline Height & 167.0 & 155.0 & 177.0 & 167.0 & 169.0 & 155.0 & 182.0 & 168.0 \\
\hline Fat levels (kg) & 14.9 & 5.8 & 25.8 & 14.6 & 34.6 & 19.8 & 64.9 & 31.4 \\
\hline Fat percentage (\%) & 25.0 & 13.4 & 37.3 & 25.2 & 38.6 & 29.5 & 51.9 & 36.8 \\
\hline Water (l) & 32.0 & 25.6 & 40.8 & 30.9 & 38.8 & 30.7 & 47.8 & 38.6 \\
\hline Non-fatty tissue (kg) & 43.7 & 34.8 & 55.7 & 42.4 & 52.1 & 42.0 & 65.5 & 52.7 \\
\hline Skeletal muscle (kg) & 23.9 & 18.8 & 31.1 & 23.5 & 29.5 & 23.1 & 37.0 & 29.4 \\
\hline Visceral fat levels (optimum $<10$ )* & 5.8 & 2 & 13 & 6 & 15.5 & 8 & 26 & 14.5 \\
\hline WHR & 0.85 & 0.76 & 0.86 & 0.85 & 0.97 & 0.82 & 1.13 & 0.97 \\
\hline Basal metabolism values (kcal) & 1314 & 1123 & 1574 & 1286 & 1516 & 1278 & 1784 & 1508 \\
\hline
\end{tabular}

The measured data point to the fact that it is imperative to evaluate individuals by other parameters and not only by the body mass index (BMI). BMI is usually associated with the risk of certain diseases, but we can assume that women with high body weight may have slightly increased body fat. On the contrary, women with optimal BMI may have a higher amount of fatty tissue. Some surveyed lifestyle parameters were selected and compared in groups of women with low and high body weight (Table 2).

The difference can be observed in physical activities, where $27 \%$ of women with low body weight and $13 \%$ of women with high body weight focus on movement more than 3 times a week. This is also related to the assessment of one's physical condition. The obtained data show that $47 \%$ of respondents with low body weight describe their physical condition as good or excellent, while $25 \%$ of respondents with high body weight state the same. Only $4 \%$ of women with low body weight, but $19 \%$ of respondents with high body weight described their physical condition as poor.
We can assume that the higher frequency of meals during the day, which was found in $44 \%$ of respondents with high body weight, may be related to higher energy intake during the day -and thus induce an increase in body weight or BMI values.

15 low-weight respondents have up to 5 friends, 19 have 5-10 friends, and the remaining 15 respondents have more than 10 friends. 19 (39\%) respondents with low body weight state that they have problematic relationships with their surroundings, family, or work, and 6 (12\%) respondents are somewhat or entirely dissatisfied with their job. On the contrary, 32 (65\%) of them are satisfied with their job. 9 highbody-weight respondents have up to 5 friends, 12 have 5-10 friends, and the remaining 11 respondents have more than 10 friends; 11 (34\%) respondents have problematic relationships with their surroundings, family, or work; 4 (12.5\%) are dissatisfied with their job, and 17 (53\%) respondents are satisfied with it.

Table 2. Selected aspects of lifestyle and data obtained from respondents by BMI $(\boldsymbol{N}=\mathbf{8 1})$

Parameter

Low-weight group $\mathrm{BMI}<25 \mathrm{~kg} / \mathrm{m}^{2}(n=49)$

A minimum daily consumption of 3 pcs of fruit

Fruit 1-2x a day

3 daily portions of food

5 daily portions of food

Experience with diet

Smoking

Abstinent (alcohol)

Physical activity more than $3 \times$ a week

Personal assessment of physical condition - "good" or "excellent"

Personal assessment of physical condition - "poor"

Average sleeping time (hrs.)

Time from waking up to breakfast - max. 60 minutes

Last meal 2 or more hours before sleep

Satisfaction with employment (1-5)

\begin{tabular}{cccc}
\hline 11 & $22 \%$ & 17 & $53 \%$ \\
41 & $84 \%$ & 21 & $66 \%$ \\
8 & $16 \%$ & 5 & $16 \%$ \\
17 & $35 \%$ & 14 & $44 \%$ \\
14 & $29 \%$ & 25 & $78 \%$ \\
6 & $12 \%$ & 6 & $19 \%$ \\
10 & $20 \%$ & 11 & $34 \%$ \\
13 & $27 \%$ & 4 & $13 \%$ \\
23 & $47 \%$ & 8 & $25 \%$ \\
2 & $4 \%$ & 6 & $19 \%$ \\
7.6 & - & 7.5 & - \\
\hline 38 & $78 \%$ & 25 & $78 \%$ \\
\hline 24 & $49 \%$ & 26 & $81 \%$ \\
2.20 & - & 2.44 & - \\
\hline
\end{tabular}

High-weight group $\mathrm{BMI}<25 \mathrm{~kg} / \mathrm{m}^{2}(n=32)$ 


\section{The quality of life of respondents by BMI in comparison with population standards}

BMI values were evaluated by the WHOQOL-BREF questionnaire in groups. The data of both groups were compared with population standards (Dragomirecká and Bartoňová, 2006). Respondents' quality of life scores and population norms are shown in Table 3. It is clear that in the physical health and psychological domains, both groups of respondents had lower values than population norms. All respondents achieved a higher score in the environment domain than population norms. Women with low body weight achieved a higher score in the social relations domain and two independently assessed questions, i.e., the quality of life and health satisfaction. On the other hand, respondents with high body weight scored lower in this domain (social relations) and two separate questions compared to population norms.

Respondents with low body weight achieved higher values in self-assessment questions Q1 (quality of life) and Q2 (satisfaction with health) than the second group of respondents and the population norms. We can conclude that higher quality of life and health satisfaction are higher at lower body weight (lower BMI).

Table 3. Population norms in WHOQOL-BREF domains and found values

\begin{tabular}{|c|c|c|c|}
\hline Domains & $\begin{array}{l}\text { Population norms } \\
\left(n=310, \text { resp. } 308^{1}\right)^{*}\end{array}$ & $\begin{array}{c}\text { Respondents } \\
\mathrm{BMI}<25 \mathrm{~kg} / \mathrm{m}^{2} \quad(n=49)\end{array}$ & $\begin{array}{c}\text { Respondents } \\
\mathrm{BMI}>25 \mathrm{~kg} / \mathrm{m}^{2} \quad(n=32)\end{array}$ \\
\hline & Average $\pm s$ & Average $\pm s$ & Average $\pm s$ \\
\hline Domain 1 (physical health) & $15.55 \pm 2.55$ & $12.85 \pm 1.65$ & $13.25 \pm 2.09$ \\
\hline Domain 2 (psychological) & $14.78 \pm 2.43$ & $13.99 \pm 2.59$ & $12.94 \pm 2.15$ \\
\hline Domain 3 (social relationships) & $14.98 \pm 2.89$ & $16.19 \pm 2.76$ & $14.54 \pm 3.12$ \\
\hline Domain 4 (environment) & $13.30 \pm 2.08$ & $15.64 \pm 1.90$ & $14.71 \pm 2.05$ \\
\hline Q1 quality of life & $3.82 \pm 0.72$ & $4.00 \pm 0.65$ & $3.75 \pm 0.72$ \\
\hline Q2 satisfaction with health & $3.68 \pm 0.85$ & $4.12 \pm 0.67$ & $3.59 \pm 0.84$ \\
\hline
\end{tabular}

\section{Discussion}

The quality of life of the respondents was determined using the WHOQOL-BREF questionnaire. The respondents achieved a lower score in the physical health and psychological domains than population norms.

Pan et al. (2011) used the same tool to achieve the same result with their respondents. They found lower scores in these two domains compared to population standards. However, their research group included people with a BMI over $27 \mathrm{~kg} / \mathrm{m}^{2}$. According to Hwang et al. (2020), the quality of life decreases with an increased waist circumference more than with other parameters that rate a person as obese. The value of visceral fat, which was significantly higher in respondents with high body weight, testifies to the storage of fat in the abdomen. Furthermore, when evaluating our respondents' WHR, we found that the average WHR of the respondents with low body weight reached the value of 0.86 , while the average value of the respondents with high body weight was 0.97 .

Hwang et al. (2020) point to a decrease in the quality of life by reducing the amount of skeletal muscle or bone tissue. The psychological domain of the quality of life assessment is not significantly affected by the unfavourable body composition.

However, when we compare our respondents in the psychological domain with population norms, the achieved score of all respondents we monitored was lower, while respondents with high body weight reached lower values than those with low body weight. We cannot say whether the decrease is related to unfavourable body composition, but it could probably be related to increased body weight.

Mikkola et al. (2020) found that higher fatty tissue levels are associated with lower quality of life, especially regarding physical health. Our respondents in the physical health do- main achieved a lower score compared to population norms. Women with low body weight, but also with high body weight, achieved lower values. At the same time, high body weight respondents achieved a surprisingly higher score in the physical health domain than low body weight respondents.

Dulloo et al. (2017) focused on nutrition, exercise, and sleep. According to the authors, these independent factors increase the risk of obesity and/or cardiometabolic diseases. The authors also mention that sleep as a risk factor for obesity cannot be based solely on its length or quality. This fact is in line with our data, where the length of sleep did not differ between women with different BMI values. Burgess et al. (2017) point to the issue of programmes focused on lifestyle changes of obese people. They state that the patients' motivation appears to be problematic, as well as dissatisfaction with the insufficiently fast effect. However, increasing patient adherence to therapy increases the chances of improving lifestyle and reduces the risk of diseases of civilization.

BMI is a frequently used parameter, especially for its simplicity. We often infer the amount of body fat from the BMI value and assume that the amount of fat will increase with increasing BMI. As early as 1998, the American Society of Endocrinologists also defined obesity using body fat. They stated that women with more than $35 \%$ of body fat and men with more than $25 \%$ of body fat are defined as obese (Dickey et al., 1998). This publication mentioned that some people might have a physiological BMI value, but the amount of fat may be increased, or they may have a higher BMI and levels of muscle mass, and they are not obese (Dickey et al., 1998). Romero-Corral et al. (2010) state that the main limitation of BMI is its inability to differentiate between fat and muscle tissue, so some individuals may be incorrectly classified as obese, and low-weight but high-fat individuals may have normal BMI. Romero-Corral et al. (2010) also provide definitions of obesity 
subtypes arranged chronologically. In 1981, Ruderman et al. (1981) spoke of metabolically active average weight. In 2004, Karelis et al. (2004) showed a subtype of obesity, "metabolically healthy obesity", in which the amount of fatty tissue is increased, the metabolic profile is standard, and insulin sensitivity is high.
The proportion of body fat increases with age. Some authors have focused their research on the amount of fatty tissue in selected population groups. They are divided mainly by age, gender, or race. The data of selected authors' data and the data that we found are shown in Table 4.

Table 4. The proportion of body fat in women of selected age by BMI

\begin{tabular}{|c|c|c|c|c|c|}
\hline & \multirow{2}{*}{ Age } & \multicolumn{4}{|c|}{ Proportion of fat (\%) } \\
\hline & & $\mathrm{BMI}<18,5 \mathrm{~kg} / \mathrm{m}^{2}$ & BMI $<25 \mathrm{~kg} / \mathrm{m}^{2}$ & $\mathrm{BMI} \geq 25 \mathrm{~kg} / \mathrm{m}^{2}$ & $\mathrm{BMI} \geq 30 \mathrm{~kg} / \mathrm{m}^{2}$ \\
\hline \multirow{2}{*}{ Gallagher et al. (2000) } & $20-39$ & $21 \%$ & - & $33 \%$ & $39 \%$ \\
\hline & $40-59$ & $23 \%$ & - & $35 \%$ & $41 \%$ \\
\hline \multirow{3}{*}{ Pasco et al. (2014) } & $20-29$ & - & - & $36 \%$ & $43.4 \%$ \\
\hline & $30-39$ & - & - & $36.2 \%$ & $43.6 \%$ \\
\hline & $40-49$ & - & - & $36.4 \%$ & $43.8 \%$ \\
\hline \multirow{2}{*}{ Heo et al. (2012) } & $18-29$ & $26.9 \%$ & $37 \%$ & - & $41.8 \%$ \\
\hline & $30-49$ & $27.5 \%$ & $37.4 \%$ & - & $42.4 \%$ \\
\hline Our research & $18-41$ & \multicolumn{2}{|c|}{$25 \%$} & \multicolumn{2}{|c|}{$38.6 \%$} \\
\hline
\end{tabular}

Gallagher et al. (2000) created a predicted body fat (\%) table for each sex, age, and BMI. For comparison, we use a table of expected amounts of fat for women. The group we are monitoring, i.e., women aged 18-41 should, according to Gallagher et al. (2000), have $21 \%$ of body fat at a BMI $<18.5 \mathrm{~kg} / \mathrm{m}^{2}$ in the age group of 20-39 years and $23 \%$ of body fat in the age group of 40-59 years. They also mention the values for women in these age categories with a BMI equal to or higher than $25 \mathrm{~kg} / \mathrm{m}^{2}$, which corresponds to $33 \%$ or $35 \%$. For women with a BMI equal to or higher than $30 \mathrm{~kg} / \mathrm{m}^{2}$, the expected fat content is $39 \%$ or $41 \%$.

Pasco et al. (2014) state the amount of body fat to define overweight and obesity by age. Women aged 20-29 are overweight if they have $36 \%$ of body fat, and obese if they have $43.4 \%$ of body fat. For women aged $30-39$, it is $36.2 \%$ and $43.6 \%$ of body fat. For women aged $40-49$ years, it is $36.4 \%$ and $43.8 \%$ of body fat (Pasco et al., 2014).

Our group of respondents confirmed that the average body fat increases with BMI. The median values are higher in women with high body weight or BMI. In women with high body weight, body fat averages at 38.6\% (29.5-51.9\%). According to Gallagher et al. (2000), these body fat values correspond to obesity. According to Pasco et al. (2014), these body fat values are slightly increased compared to those found for overweight. Among our respondents with high body weight, we found those who, according to the proportion of body fat, would be among women with adequate body weight by BMI (BMI 18.5$25.0 \mathrm{~kg} / \mathrm{m}^{2}$ ). We also found those who belong to the group of underweight people according to the proportion of fat in their body by their BMI (BMI $\left.<18.5 \mathrm{~kg} / \mathrm{m}^{2}\right)$. The highest value found among respondents with high body weight was $51.9 \%$, which is significantly higher than the expected value of $33 \%$ or $35 \%$, but also $39 \%$ or $41 \%$. Our low body weight group achieved values of up to $37.3 \%$ of body fat, which corresponds to a much higher BMI (even above $30 \mathrm{~kg} / \mathrm{m}^{2}$ ) according to Gallagher et al. (2000). Low body weight respondents' average body fat levels were at $25 \%(13.4-37.3 \%)$.

Heo et al. (2012) also dealt with the amount of fat. Caucasian women with an average BMI of $27.7 \pm 0.2 \mathrm{~kg} / \mathrm{m}^{2}$ had an average body fat of $39.6 \pm 0.2 \%$. These authors state the expected proportion of body fat with value limits. We use a body fat percentage (\%) limit for Caucasian women. They are $26.9 \%$ for women aged $18-29$ at a BMI of $18.5 \mathrm{~kg} / \mathrm{m}^{2}, 37 \%$ at a BMI of $25 \mathrm{~kg} / \mathrm{m}^{2}$, and $41.8 \%$ at a BMI of $30 \mathrm{~kg} / \mathrm{m}^{2}$. For the age category 30-49 years and equal BMI values, the limit values for the amount of fat are 27.5 , or 37.4 , or $42.4 \%$ of body fat.

Heo et al. (2012) state that, in the individual age groups mentioned above, and partially or fully correspond with our study groups, there were situations where subjects had higher body fat levels, which could correspond to a BMI of $25 \mathrm{~kg} / \mathrm{m}^{2}$. However, their BMI was less than $25 \mathrm{~kg} / \mathrm{m}^{2}$. A similar situation occurred in subjects with a BMI below $30 \mathrm{~kg} / \mathrm{m}^{2}$, where the fat percentage would correspond to a BMI of $30 \mathrm{~kg} / \mathrm{m}^{2}$. This situation occurred in $7.0-18.4 \%$ of Caucasian women. This happened more often in women with a BMI below $25 \mathrm{~kg} / \mathrm{m}^{2}$.

Goossens (2017) states that fatty tissue levels are a more accurate parameter for metabolic risk assessment than BMI. However, he also says that the total amount of fat does not fully reflect the metabolic health at the individual level. Therefore, according to the author, it is necessary to focus on the distribution of fatty tissue in the body. Fat storage in the abdomen poses a higher risk than fat storage in the buttocks and thighs. Goossens (2017) also mentions the term "metabolically healthy obesity" (metabolically healthy obese). Such a person is not at risk of cardiometabolic diseases. There is no dyslipidemia, insulin resistance, prediabetes, or diabetes mellitus type 2. Blüher (2014) points out that, although the health of the obese person may not be at risk of metabolic diseases, it is helpful to discuss whether these individuals are really healthy. He states that these individuals may be affected by psychosocial factors, reduced fitness, chronic pain, or respiratory diseases, etc., which may impair their health.

\section{Conclusions}

We used anthropometric data and found that body fat levels, WHR, basal metabolism, body water, muscle mass and abdominal fat are higher in people with higher BMI. Respondents with low body weight had higher fatty tissue levels, and some had an increased value of visceral fat. This may indicate that 
adequate BMI does not always mean individual tissue levels in the body are standard. Physiological BMI does not imply a lower risk of certain diseases. It is advisable to undergo examinations using bioimpedance, which is quick and easy.

We found that women with high body weight often consume at least 3 pieces of vegetable a day. Most of them eat five times a day and have experience with a diet.

Most of them smoke but do not consume alcohol. These women are less often engaged in physical activity, and therefore fewer of them assess their physical condition positively. Some even consider their physical condition to be poor.
We found a higher quality of life and health satisfaction among respondents with low body weight. Both groups achieved a higher score regarding social relationships compared to the population standards. On the contrary, both groups achieved lower values and a lower quality of life regarding physical health and psychological domain.

It is appropriate to continue the research and expand the study to generalise our data.

\section{Ethical aspects and conflict of interests}

The authors have no conflict of interests to declare.

\section{Vliv životního stylu na kvalitu života a složení těla žen v produktivním věku}

\section{Souhrn}

Nadváha a obezita patří mezi civilizační choroby. Nadbytečná tělesná hmotnost způsobuje další onemocnění. Často je nadměrná tělesná hmotnost přičinou zhoršené kvality života.

Cíl: Cílem práce bylo zhodnotit vybrané zdravotně sociální aspekty ve vztahu ke správné výživě. Zjistit, jak životní styl ovlivňuje BMI, složení těla, zejména zastoupení tukové tkáně, identifikovat vztah mezi hodnotami BMI a kvalitou života, porovnat kvalitu života respondentů s populačními normami a zjistit, zda mezi jednotlivými ukazateli existují rozdíly v závislosti na BMI.

Metodika: Pro hodnocení obezity jsme využili BMI. Zmapovali jsme vztah mezi tělesnou hmotností, tělesným složením, životním stylem a kvalitou života. Data jsme získali použitím dotazníků. První dotazník se zaměřoval na životní styl respondentů. Jako druhý byl použit standardizovaný dotazník WHOQOL-BREF. Dále respondenti podstoupili analýzu složení těla pomocí bioimpedance př́strojem InBody 270. Výzkumný soubor tvořilo 81 žen ve věku 18-41 let. Soubor byl rozdělený do dvou skupin dle hodnot BMI.

Výsledky: Průměrná hodnota BMI ve skupinách žen rozdělených dle BMI byla $20,9 \mathrm{~kg} / \mathrm{m}^{2}\left(16,7-24,3 \mathrm{~kg} / \mathrm{m}^{2}\right)$, podíl tělesného tuku průměrně $24,8 \%(13,4-37,3 \%)$, resp. $30,8 \mathrm{~kg} / \mathrm{m}^{2}\left(25,4-44,8 \mathrm{~kg} / \mathrm{m}^{2}\right)$, podíl tělesného tuku průměrně $38,9 \%(29,5-51,9 \%)$. U životního stylu se rozdíly objevily ve frekvenci konzumace jídel a v cílené pohybové aktivitě. Při srovnání kvality života s populačními normami se vyskytovaly rozdíly ve všech hodnocených doménách.

Kličová slova: BMI; kvalita života; tělesné složení; WHOQOL-BREF; životní styl

\section{References}

1. Blüher M (2014). Are metabolically healthy obese individuals really healthy? Eur J Endocrinol 171(6): R209-219. DOI: 10.1530/EJE-14-0540.

2. Burgess E, Hassmén P, Pumpa K (2017). Determinants of adherence to lifestyle intervention in adults with obesity: a systematic review: a systematic review. Clin Obes 7(3): 123-135. DOI: 10.1155/2013/285680.

3. Dickey RA, Bartuska D, Bray GW, Callaway W, Davidson ET, Feld S, et al. (1998). AACE/ACE position statement on the prevention, diagnosis, and treatment of obesity. Endocr Pract 4(5): 297-350.

4. Donini L, Poggiogalle E, Del Balzo V, Lubrano C, Faliva M, Opizzi A, et al. (2013). How to estimate fat mass in overweight and obese subjects. Int J Endocrinol 2013: 285680. DOI: $10.1155 / 2013 / 285680$.

5. Dragomirecká E, Bartoňová J (2006). WHOQOL-BREF, WHOQOL-100: World Health Organization Quality of Life Assessment: příručka pro uživatele české verze dotazníků kvality života Světové zdravotnické organizace. Praha: Psychiatrické centrum, 88 p.

6. Dulloo A, Miles-Chan JL, Montani J-P (2017). Nutrition, movement and sleep behaviours: their interactions in pathways to obesity and cardiometabolic diseases: their interactions in pathways to obesity and cardiometabolic diseases. Obes Rev 18(Suppl. 1): 3-6. DOI: 10.1111/obr.12513.

7. Dvořáčková D (2012). Kvalita života seniorů: v domovech pro seniory. Praha: Grada, 112 p.

8. Gallagher D, Heymsfield S, Heo M, Jebb S, Murgatroyd P, Sakamoto Y (2000). Healthy percentage body fat ranges: an approach for developing guidelines based on body mass index: an approach for developing guidelines based on body mass index. Am J Clin Nutr 72(3): 694-701. DOI: 10.1093/ ajcn/72.3.694.

9. Goossens GH (2017). The Metabolic Phenotype in Obesity: Fat Mass, Body Fat Distribution, and Fatty Tissue Function: Fat Mass, Body Fat Distribution, and Fatty Tissue Function. Obes Facts 10(3): 207-215. DOI: 10.1159/000471488.

10. Heo M, Faith MS, Pietrobelli A, Heymsfield SB (2012). Percentage of body fat cutoffs by sex, age, and race-ethnicity in the US adult population from NHANES 1999-2004. Am J Clin Nutr 95(3): 594-602. DOI: 10.3945/ajcn.111.025171.

11. Hwang A-C, Lee W-J, Peng L-N, Liu L-K, Lin M-H, Loh C-H, Chen L-K (2020). Unfavorable body composition and quality of life among community-dwelling middle-aged and older adults: What really matters? Maturitas 140: 34-40. DOI: 10.1016/j. maturitas.2020.05.024.

12. Karelis AD, St-Pierre DH, Conus F, Rabasa-Lhoret R, Poehlman ET (2004). Metabolic and body composition factors in subgroups of obesity: what do we know? J Clin Endocrinol Metab 89(6): 2569-2575. DOI: 10.1210/jc.2004-0165.

13. Mikkola TM, Kautiainen H, von Bonsdorff MB, Salonen MK, Wasenius N, Kajantie E, Eriksson JG (2020). Body composition and changes in health-related quality of life in older age: a 10year follow-up of the Helsinki Birth Cohort Study: a 10-year follow-up of the Helsinki Birth Cohort Study. Qual Life Res 29(8): 2039-2050. DOI: /10.1007/s11136-020-02453-1.

14. Pan H-J, Cole BM, Geliebter A (2011). The benefits of body weight loss on health-related quality of life. J Chin Med Assoc 74(4): 169-175. DOI: 10.1016/j.jcma.2011.01.038.

15. Pasco JA, Holloway KL, Dobbins AG, Kotowicz MA, Williams LJ, Brennan SL (2014). Body mass index and measures of body 
fat for defining obesity and underweight: a cross-sectional, population-based study: a cross-sectional, population-based study. BMC Obes 1: 9. DOI: 10.1186/2052-9538-1-9.

16. Romero-Corral A, Somers VK, Sierra-Johnson J, Korenfeld Y, Boarin S, Korinek J, et al. (2010). Normal weight obesity: a risk factor for cardiometabolic dysregulation and cardiovascular mortality: a risk factor for cardiometabolic dysregulation and cardiovascular mortality. Eur Heart J 31(6): 737-746. DOI: 10.1093/eurheartj/ehp487.

17. Ruderman NB, Schneider SH, Berchtold P (1981). The "metabolically-obese", normal-weight individual. Am J Clin Nutr 34(8): 1617-1621. DOI: 10.1093/ajcn/34.8.1617.
18. WHO (2021a). Obesity. [online] [cit. 2021-09-11]. Available from: https://www.who.int/health-topics/obesity\#tab=tab_1

19. WHO (2021b). Obesity and overweight [online] [cit. 2021-0910]. Available from: https://www.who.int/news-room/factsheets/detail/obesity-and-overweight

20. Zhou Y, Höglund P, Clyne N (2019). Comparison of DEXA and Bioimpedance for Body Composition Measurements in Nondialysis Patients with CKD. J Ren Nutr 29(1): 33-38. DOI: 10.1053/j.jrn.2018.05.003. 